\title{
The Impact of Increased Alcohol Production on Agriculture: A Simulation Study
}

\author{
Steven B. Webb
}

The higher prices of petroleum and risks of an Organization of Petroleum Exporting Countries (OPEC) embargo have stimulated the search for alternative liquid motor fuels, including alcohol from renewable sources (Alcohol Fuels Policy Review, Office of Technology Assessment, Paul). Any plant matter can be converted to alcohol, but in the near future the main input in the United States will be corn, because the technology for using the other inputs is not yet so well developed.

The federal and some state governments have enacted tax exemptions for fuel mixtures that include grain alcohol, i.e., gasohol. Because the alcohol content of gasohol is only $10 \%$, the effective subsidy per gallon of alcohol is ten times the amount of the tax exemption. So, exemption from the $4 x$ federal tax gives an effective subsidy of $40 x$ per gallon of alcohol, and the effective state subsidies add on another $10 \propto$ to a dollar (in Iowa) per gallon of alcohol (Alston, p. 10). The wholesale price of ethanol is less than a dollar above the pretax wholesale price of gasoline. The enacted subsidies are, therefore, inducing rapid increases in the production and consumption of fuel alcohol. Furthermore, a recent study predicts that after the mid-1980s, fuel alcohol will be increasingly economically attractive even without the subsidy (Schnittker Associates, p. 44).

The supply curve of grain alcohol depends chiefly upon the supply of corn and other feedstocks and upon the supply of capital and labor. In the intermediate and long-run (five years or more), one can assume an infinitely elastic supply of labor and capital to an industry as small as grain alcohol would be even under the most grandiose schemes. Federally subsidized loans for alcohol distilleries will further assure that the supply price of capital does not rise as the industry expands. The slope of the alcohol supply curve will depend chiefly on (in)elasticities of supply and demand in the agricultural sector. Agricultural inputs currently account for over half the cost of grain alcohol.

This paper seeks in one sense to estimate the

Steven B. Webb is an assistant professor, Department of Economics, University of Michigan.

The author wishes to thank Terry Alston, Joe Asbury, Leroy Quance, Wally Tyner, two referees, and especially Dave Watt for their many valuable suggestions. Any errors that remain are, of course, the responsibility of the author. upward slope of the supply curve of ethanol by estimating the response of agricultural prices to various levels of corn alcohol production. An alcohol fuel program is, on the other hand, an agricultural policy as well as an energy policy. So a second purpose of this paper is to predict the impact of increased alcohol fuel production on important dimensions of U.S. agriculture.

The first section of the paper will describe in detail the linkages between agriculture and alcohol production from corn. The next section tells some relevant features of the model used for the simulation-the U.S. Department of Agriculture's (USDA) NIRAP - and describes the results of the simulation experiments. U.S. agriculture appears well able to adapt to the impact of increased alcohol production. Consequently, the upward slope of the alcohol supply curve will be modest. The third section of the paper describes this supply curve and some other wider implications of the simulations.

\section{The Linkage of Alcohol and Agriculture}

The connections between the grain alcohol industry and agriculture may be described in two ways. The demand for agricultural commodities will shift in terms of quantity as a function of the volume of alcohol output. Likewise, the cost of producing alcohol will depend on the price of agricultural commodities.

\section{Physical Flows}

Producing a gallon of alcohol requires 0.4 bushels of corn. So, we shall model the input for a fuel alcohol program as an outward shift in the demand curve for corn, a shift whose size is directly proportional to the size of the program. Distillation from corn yields marketable by-products, whose value reduces the cost of alcohol production by about onefourth (Alston, p. 6; Office of Technology Assessment, pp. 11-12; Meekhof, Gill, Tyner, p. 15). Conventionally this by-product is a mash, which when dried is marketed as distillers dry grain (DDG). Production of a gallon of alcohol yields 6.8 pounds of DDG; as cattle fodder it will substitute for about 3.4 pounds of soybean meal. In order to save the cost of drying the mash into DDG, many 
plans call for using the mash wet in feedlots adjacent to distilleries. In either case, though, we can assume the same ratio of substitution between soybean meal and by-products per gallon of alcohol obtained by conventional dry milling. It is also possible to produce ethanol from corn by a wet milling process that yields corn oil and gluten meal as byproducts (Alston, p.5). As DDG displaces some soybean meal in the fodder market, it will become desirable to have corn oil replace corresponding amounts of soybean oil. Therefore, a mix of the dry milling and wet milling processes probably will emerge. Because dry milling produces more alcohol per bushel of corn, and because soybeans are about four-fifths meal, dry milling will be the basis for the simulation here. The price of soybean meal per weight is just over four-fifths the price of soybeans. So a pound of DDG is equivalent to about two-fifths of a pound of soybeans, and each gallon of alcohol will yield by-products equivalent to about .045 bushels of soybeans. ${ }^{I}$ We can, in short, model the impact of each billion gallons of alcohol production by shifting out the corn demand curve by 400 million bushels and shifting in the soybean demand curve by 45 million bushels.

\section{Price Linkage}

Both the input and output flows between alcohol distillation and agriculture contribute to the upward slope of the alcohol supply curve. Obviously, as increased alcohol production shifts out the demand curve for corn, the resulting higher price of corn will raise the cost of alcohol production. Increased alcohol production also would increase the supply and thus drive down the price of the byproducts-DDG-and of the soybeans for which they substitute. Lower prices for by-products raise the total cost of the alcohol. With corn selling at $\$ 3.70$ per bushel in December 1980 and DDG at $\$ 120$ per ton (half the price of soybean meal) and with $20 \%$ inflation of Alston's estimate of other costs ( $\$ .55 / \mathrm{gal}$. in 1978 dollars, p. 6 ), ethanol would cost $\$ 1.67$ a gallon. Each percentage point rise in the price of corn would raise the cost of ethanol $0.85 \%$, and each percentage point fall in the price of DDG would raise ethanol cost $0.25 \%$.

\section{Simulation with NIRAP}

The National Interregional Agricultural Projection (NIRAP) system is a computerized simulation model of the U.S. agricultural sector. A model of this complexity is necessary because of the numerous interactions that would take place as alcohol production simultaneously increased the demand for corn and the supply of a soybean substitute (DDG). Marginal land would be drawn into corn

\footnotetext{
1 One gallon of ethanol yields $6.8 \mathrm{lb} . \mathrm{DDG}=3.4 \mathrm{lb}$. soybean meal $=2.7 \mathrm{lb}$. soybeans $=.045$ bushels of soybeans.
}

cultivation. There would be substitutions in production as land was switched to corn from other crops, especially soybeans. There would be substitution in fodder usage, soybeans for corn. There would be substitution in animal raising and in meat consumption as animals needing relatively more soybeans (cattle) were substituted for those needing mostly corn (hogs and chickens). Exports would react to any changes in domestic prices. NIRAP incorporates these interactions into its simulations.

\section{Simulations}

For the principal set of simulations, alcohol fuel output was 10 billion gallons annually. This is an upper bound on eventual production levels, since it would almost suffice for gasohol completely to replace straight gasoline at current levels of use. Ten billion gallons of alcohol per year would require corn inputs equal to about half of current U.S. production. The structure of the NIRAP model is such that the effects of alcohol production are not exactly proportional to the volume of alcohol produced. So some results from simulations of 5 billion gallons of alcohol per year are reported to give the reader a sense of the nonlinearities.

Shifts in the export demand curves simulated the impact of a fuel alcohol program. The export demand curve for corn was shifted up by an amount corresponding to the input requirements for fuel alcohol production, and the export demand curve for soybeans was shifted down by an amount corresponding to the by-product output of 1979 and 1985. A longer phase-in period, 1979 to 1990 , yielded similar results.

\section{Measures of Impact}

To measure the impact of grain ethanol production, the outcomes in various scenarios are compared with a base case in which there is no alcohol production and also no explicit government price support programs. The NIRAP projections include a rate of inflation, which is certainly realistic in general but is not likely to be precisely accurate in predicting price levels ten or twenty years hence. So, the differences between values in the base case and those in the simulated scenarios are reported as percentage changes from the base case value. Table 1 reports for several simulations the percentage changes in some of the key variables in agriculture.

For the purpose of estimating the slope of the ethanol supply curve, the changes in the price of corn and soybeans are most relevant.

For the purpose of understanding how the structure of agricultural production and consumption will change in response to large-scale ethanol production, we also want to look at changes in other key prices-wheat, beef, and pork. Even more revealing will be the changes in the production quantities of corn, soybeans, wheat, and meat, and in the amounts of these commodities that are exported. 
Table 1. Projected Effects of Grain Alcohol Production on Selected Variables in the Agricultural Sector

\begin{tabular}{|c|c|c|c|c|c|c|c|}
\hline Column & 1 & 2 & 3 & 4 & 5 & 6 & 7 \\
\hline $\begin{array}{l}\text { Alcohol output (billion gal./yr.) } \\
\text { Year } \\
\text { Corn inputs (million bu./yr.) }\end{array}$ & $\begin{array}{r}5 \\
1990 \\
2,000\end{array}$ & $\begin{array}{r}10 \\
1985 \\
4,000\end{array}$ & $\begin{array}{r}10 \\
1990 \\
4,000\end{array}$ & $\begin{array}{r}10 \\
2000 \\
4,000\end{array}$ & $\begin{array}{r}10 \\
1985 \\
4,000\end{array}$ & $\begin{array}{r}10 \\
1990 \\
4,000\end{array}$ & $\begin{array}{r}10 \\
2000 \\
4,000\end{array}$ \\
\hline $\begin{array}{l}\text { By-product output (soybean equivalent } \\
\text { million bu./yr.) } \\
\text { Percentage changes: }\end{array}$ & 225 & 450 & 450 & 450 & 0 & 0 & , \\
\hline $\begin{array}{l}\text { Corn - price } \\
\text { output } \\
\text { exports }\end{array}$ & $\begin{array}{r}20.9 \\
20.3 \\
-5.7\end{array}$ & $\begin{array}{r}45.6 \\
37.9 \\
-8.7\end{array}$ & $\begin{array}{r}46.0 \\
42.8 \\
-7.0\end{array}$ & $\begin{array}{r}37.0 \\
35.5 \\
-5.7\end{array}$ & $\begin{array}{r}50.1 \\
37.6 \\
-9.2\end{array}$ & $\begin{array}{r}50.1 \\
42.5 \\
-7.2\end{array}$ & $\begin{array}{r}40.1 \\
35.1 \\
-6.0\end{array}$ \\
\hline $\begin{array}{l}\text { Soybeans - price } \\
\text { output } \\
\text { exports }\end{array}$ & $\begin{array}{r}-5.4 \\
-9.1 \\
4.6\end{array}$ & $\begin{array}{r}-6.8 \\
-16.3 \\
9.9\end{array}$ & $\begin{array}{c}-9.8 \\
-17.0 \\
10.1\end{array}$ & $\begin{array}{r}-9.3 \\
-15.2 \\
8.1\end{array}$ & $\begin{array}{l}9.4 \\
4.0 \\
2.2\end{array}$ & $\begin{array}{l}6.2 \\
4.2 \\
1.9\end{array}$ & $\begin{array}{l}4.1 \\
2.9 \\
0.9\end{array}$ \\
\hline $\begin{array}{l}\text { Wheat - price } \\
\text { output } \\
\text { exports }\end{array}$ & $\begin{array}{l}1.3 \\
2.5 \\
1.3\end{array}$ & $\begin{array}{l}5.8 \\
5.0 \\
3.2\end{array}$ & $\begin{array}{l}3.3 \\
5.4 \\
3.0\end{array}$ & $\begin{array}{l}1.8 \\
4.1 \\
2.0\end{array}$ & $\begin{array}{l}7.9 \\
4.9 \\
2.8\end{array}$ & $\begin{array}{l}4.9 \\
5.3 \\
2.6\end{array}$ & $\begin{array}{l}3.0 \\
3.8 \\
1.5\end{array}$ \\
\hline $\begin{array}{l}\text { Beef - price } \\
\text { output }\end{array}$ & $\begin{array}{r}-2.8 \\
0.1\end{array}$ & $\begin{array}{l}9.7 \\
0.9\end{array}$ & $\begin{array}{l}1.1 \\
0.7\end{array}$ & $\begin{array}{r}5.1 \\
+0.0\end{array}$ & $\begin{array}{r}11.3 \\
0.7\end{array}$ & $\begin{array}{l}2.2 \\
0.4\end{array}$ & $\begin{array}{r}5.8 \\
-0.4\end{array}$ \\
\hline $\begin{array}{l}\text { Pork - price } \\
\text { output }\end{array}$ & $\begin{array}{r}8.8 \\
-2.3\end{array}$ & $\begin{array}{r}21.3 \\
-3.3\end{array}$ & $\begin{array}{r}21.1 \\
-4.0\end{array}$ & $\begin{array}{r}15.4 \\
-4.0\end{array}$ & $\begin{array}{r}24.6 \\
-3.7\end{array}$ & $\begin{array}{r}22.8 \\
-4.5\end{array}$ & $\begin{array}{r}17.9 \\
-4.6\end{array}$ \\
\hline $\begin{array}{l}\text { Farm prices (aggreg. index) } \\
\text { Net farm income }\end{array}$ & $\begin{array}{l}3.6 \\
7.7\end{array}$ & $\begin{array}{l}11.2 \\
32.5\end{array}$ & $\begin{array}{r}8.3 \\
18.3\end{array}$ & $\begin{array}{r}5.9 \\
11.4\end{array}$ & $\begin{array}{l}14.1 \\
41.2\end{array}$ & $\begin{array}{l}10.5 \\
23.6\end{array}$ & $\begin{array}{r}7.4 \\
14.3\end{array}$ \\
\hline
\end{tabular}

a Compared to the base case projection with no alcohol production and no price supports. The percentage change was calculated as the difference from the base case divided by the value in the base case.

The ramifications of a fuel alcohol program for Americans' overall lifestyle show up in two variables. The changes in real net farm income show the benefits that will accrue to farmers. The changes in an index of average agricultural prices (paid to farmers) reveal the adverse impact on all consumers' budgets.

\section{Results}

The first 4 columns of table 1 show the projected values of key variables in simulations using the standard assumptions about input and output flows. Each billion gallons of alcohol requires 400 million bushels of corn and yields by-products that substitute for $\mathbf{4 5}$ million bushels of soybeans. The maximum levels of alcohol production-5 billion gallons annually for column 1 and 10 billion gallons for columns 2-4-are reached by 1985 and maintained thereafter.

\section{Price Effects}

Corn's price reacts most dramatically to alcohol production. Each additional billion gallons of alcohol per year raises the price of corn by about $4 \%$. The relationship between alcohol production and corn price is linear in logarithms; each additional billion gallons of alcohol raises the natural logarithm of the corn price by the same amount,
0.038 in 1990. Alcohol production drives down soybean prices, as one would expect, because of the by-product DDG substituting for soybean meal. The relation for soybeans is complicated, however, by the substitution with corn in both production and consumption, induced by the strong rise in the price of corn. Still we can say that each additional billion gallons of alcohol production per year will lower the price of soybeans and their substitutes (DDG) on the order of $1 \%$. This is not out of line with the findings of Meekhof, Tyner, and Holland, using a model with only corn and soybeans, that increasing ethanol production from 1 to 2 billion gallons would raise the price of corn $5.5 \%$ in the early $1980 \mathrm{~s}$ and lower the price of soybeans $2 \%$.

Alcohol production also affects prices of commodities not directly involved. Wheat prices would rise, but only about half a percent for every billion gallons of alcohol annually. Pork prices reflect the effects of higher feeding costs, with the percentage rise in projected pork prices being almost half as large as the percentage rise in corn prices. Beef prices react to at least three influences: high pork prices shift consumer demand toward beef; high corn prices raise the production cost of beef; and falling soybean prices lower costs. Because the last effect goes in the opposite direction from the first two and because the effects are nonlinear, beef prices fall for low levels of alcohol production and rise for high levels. The overall index of prices paid to farmers goes up a percentage point or less per 
billion gallons of alcohol output. Although the effect on the overall consumer price index would be imperceptible, the rise in meat prices would be noticed and might arouse political opposition to gasohol subsidies.

\section{Output Effects}

Increased alcohol production would push up corn output almost as much as corn prices. The percentage of decline in soybean production is, on the other hand, around twice the percentage of decline in price. This happens because the increased availability of DDG shifts the soybean demand curve leftward, while the switching of land from soybeans to corn shifts the soybean supply curve also to the left. Wheat output increases in order to fill the increased need for corn substitutes. One can visualize the wheat-growing regions expanding slightly, perhaps at the expense of the corn-soybean regions, while the crop mix in corn-soybean regions shifts strongly toward corn. ${ }^{2}$ The small change in projected beef production reflects that the price rise resulted from nearly equal upward shifts in its supply and demand curves. The decline in pork output, much smaller than the rise in price, confirms that the supply curve shifted up along a relatively static demand curve.

\section{Exports}

The major changes in exports, caused by alcohol production, are the decline of corn exports and rise of soybean exports. Wheat exports actually rise some, presumably to fill the gap in world markets left by the decline of corn exports. The net change in the trade balance would be positive, chiefly because of the higher corn prices.

\section{Without By-Product Sales}

One of the major uncertainties about large-scale grain ethanol production is how the corresponding large output of by-products will be marketable. In other words, will one billion bushels of DDG substitute for soybeans at the same ratio that 10 million bushels do at present? The scenarios discussed so far presume that they will. Realistically, one must expect some decline in the price of DDG and other alcohol by-products relative to the price of soybean products.

To see an extreme upper bound on the effect of diminishing opportunities for utilizing alcohol byproducts, columns 5,6, and 7 of table 1 report results of a simulation where it was assumed that no alcohol by-products entered the agricultural economy. Except on soybeans, the effects in this noby-product scenario, which has the same alcohol output as columns 2,3 , and 4 , do not differ much

2 The version of the NIRAP model that. I used does not explicitly calculate the amount of land in cultivation. from the standard scenario. The prices of corn, wheat, beef, and pork rise a little more in the noby-product scenario, and their outputs rise slightly less or, in the case of pork, fall slightly more. Net farm income rises about $30 \%$ more in the no-byproduct scenario. The big change, of course, is for soybeans, whose price and output rise rather than fall.

Any other reasonable scenario for the prices and uses of by-products would yield results intermediate between those in columns $2-4$ and those in columns 5-7.

\section{Further Implications}

The previous section reports the simulated effects of increased alcohol production on the prices and flows of commodities in the agricultural sector. These changes will have some broader ramifications for the supply price of ethanol, for the income of farm households, for the efficiency losses that our society would incur by subsidizing fuel alcohol, and for the moral issue of producing fuel from grain while millions of people in the world go hungry.

\section{Ethanol Supply Curve}

The long-run ethanol supply curve starts at a height approximately equal to its current cost, $\$ 1.67$ per gallon, and slopes upward in accordance with the impact of ethanol production on agricultural prices. As described earlier, the cost of ethanol production rises $0.85 \%$ for each percentage point rise in the price of corn and $0.25 \%$ for each percentage point fall in the price of DDG. Each billion gallons of ethanol production will raise the price of corn $4 \%$ and lower the price of soybeans (DDG substitute) about $1 \%$. The ethanol supply curve will, therefore, rise $3.65 \%$ for every billion gallons of ethanol. So producing 10 billion gallons of ethanol annually, the upper bound, would push its price up $36.5 \%$, to around $\$ 2.30$ per gallon in 1980 dollars.

\section{Farm Incomes}

How the gasohol program "plays in Peoria" and elsewhere in the rural Midwest depends chiefly on what it does to farm incomes-measured by "real net farm income" in the NIRAP model. Gasohol will be a political success with farm constituencies. In 1990, every additional billion gallons of alcohol annually would raise real net farm incomes by over $1.5 \%$. The boost to net farm incomes from a given level of alcohol production appears to diminish over time. This occurs because land costs, which are netted out in the calculation of net farm income, rise in response to the greater demand for agricultural output. So if we count land rents as part of the profits of agriculture, rather than as part of the cost, then the supplement to farm income appears more accurately in the calculation for 1985: each billion 
gallons of annual alcohol production raises farm income by $2 \%$ to $3 \%$.

As a policy to augment agricultural income, ethanol production subsidies should be compared with existing price support programs. To compare current crop diversion schemes with ethanol production, the NIRAP program was run with the constraint that government payments to farmers be sufficient to give the same net farm income as in the simulation for 10 billion gallons of ethanol production. The simulated necessary government outlays were $4.4 \%$ of potentially marketable output in 1985 , $6 \%$ in 1990 , and $1.9 \%$ in 2000 . Government payments were, in comparison, below $1 \%$ in the mid1970 s but over $6 \%$ in the late 1960s (USDA 1977, p. 32).

\section{Social Costs}

Standard supply and demand analysis reveals the social cost of a fuel alcohol subsidy compared to a free market situation. The area under the fuel alcohol demand curve is the benefit to society from alcohol production-a gain divided between increased surplus for liquid fuel consumers and decreased resource costs of producing nonalcohol fuels. The area under the alcohol fuel supply curve is the resource cost of its production. So the social loss from a fuel alcohol subsidy is the area that is between the two curves, to the right of the equilibrium without a subsidy, and to the left of the equilibrium with a subsidy. When, as now, there would be virtually no fuel alcohol production without a subsidy, then the area of social loss is most of the value of the (implicit) government subsidy. The Schnittker Associates predict, however, that by 1985/86 the price of oil will have risen enough relative to the price of corn so that substantial amounts of fuel alcohol would be produced even without a subsidy (p, 44). In that event the social loss from the subsidy, if it remains, probably would be well under half the total value of the subsidy. In either case, the more responsive the agricultural sector, i.e., the more readily it diverts resources away from alternative uses and therefore the flatter the alcohol supply curve, the greater is the social cost arising from a given per gallon subsidy, and the smaller is the proportion of the subsidy that would be a pure transfer to the farmers' net income ${ }^{3}$ Clearly then, the implication of the NIRAP simulation, that the alcohol supply curve is relatively flat, means that the gasohol subsidy will be effective as an energy policy to reduce dependence on petroleum but will be a socially wasteful way to subsidize farm incomes.

\footnotetext{
3 See Webb (1981) for a fuller discussion. To the extent that present programs subsidize farm incomes by diverting some resources, e.g., land, from their highest valued uses, the social cost of replacing these programs with the fuel alcohol subsidy would be less than when compared with the free market situation.
}

Food versus Fuel

The moral question about producing fuel from resources that could feed hungry people is addressed most directly by looking at the changes in exports, especially of wheat. The main U.S. export that feeds the world's poor is wheat. Developing countries buy two-thirds of U.S. wheat exports and use them mostly for human consumption (USDA 1979 , pp. 49-50). In the NIRAP simulations, fuel alcohol production actually caused wheat exports to increase. Granted, the increased exports probably take the place of corn as fodder, but the wheat price rise is only $2 \%$ to $6 \%$ and so would do little to discourage human consumption.

\section{Conclusions}

The U.S. agricultural economy as modeled in the NIRAP program appears to be capable of adjusting without major difficulties to even high levels of fuel alcohol production. The price of corn and cost of alcohol would rise significantly but not so high as to rule out the possibility of replacing with alcohol a tenth of current gasoline consumption. This prediction of great responsiveness by American agriculture is not surprising in view of its historical ability to adjust to shocks at least as large as those resulting from high levels of alcohol production. The extensiveness of the relationships modeled in NIRAP not only gives insights into the indirect effects of increased alcohol production but also probably accounts for why the direct effects are so mitigated.

\section{[Received August 1980; revision accepted February 1981.]}

\section{References}

Alston, Terry G. Grain Alcohol as a Petroleum Substitute: A Perspective. Argonne, III.: Argonne National Laboratory Rep. ANL/SPG-9, April 1980.

Gasohol: A Technical Memorandum. Office of Technology Assessment, Washington, D.C., 1979.

Meekhof, Ronald L., Mohinder Gill, and Wallace E. Tyner. Gasohol: Prospects and Implications. USDA Agr. Econ. Rep. No. 458, Washington, D.C., June 1980.

Meekhof, Ronald L., Wallace E. Tyner, and Forrest D. Holland. "U.S. Agricultural Policy and Gasohol: A Policy Simulation." Amer. J, Agr. Econ. 62(1980):408-415.

Paul, J. K., ed. Ethyl Alcohol Production and Use as a Motor Fuel. Park Ridge, N.J.: Noyes Data Corp., 1979.

Schnittker Associates. Ethanol: Farm and Fuel Issues. Washington, D.C.: U.S. National Alcohol Fuels Commission, Aug. 1980. 
The Report of the Alcohol Fuels Policy Review. Washington, D.C.: U.S. Dep. of Energy PE 0012, 1979.

U.S.: Department of Agriculture. State Farm Income Statistics. Washington, D.C., Sept. 1977. U.S. Foreign Agricultural Trade Statistical Re- port, Calendar Year 1978, Washington, D.C., Oct. 1979.

Webb, Steven B. The Social Cost of a Subsidy for Fuel Alcohol. Argonne, Ill.: Argonne National Laboratory Rep., forthcoming. 